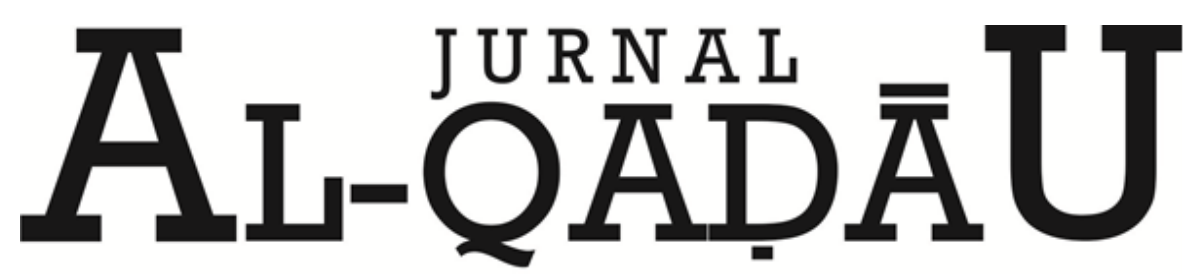

PERADILAN dan HUKUM KELUARGA ISLAM

\title{
Peradilan Agama sebagai Penegak Hukum Islam di Indonesia
}

\author{
Religious Court as Islamic Law Upholders in Indonesia
}

Andi Intan Cahyani

Dosen Fakultas Syariah dan Hukum UIN Alauddin Makassar

Email:intan_cahyani@gmail.com

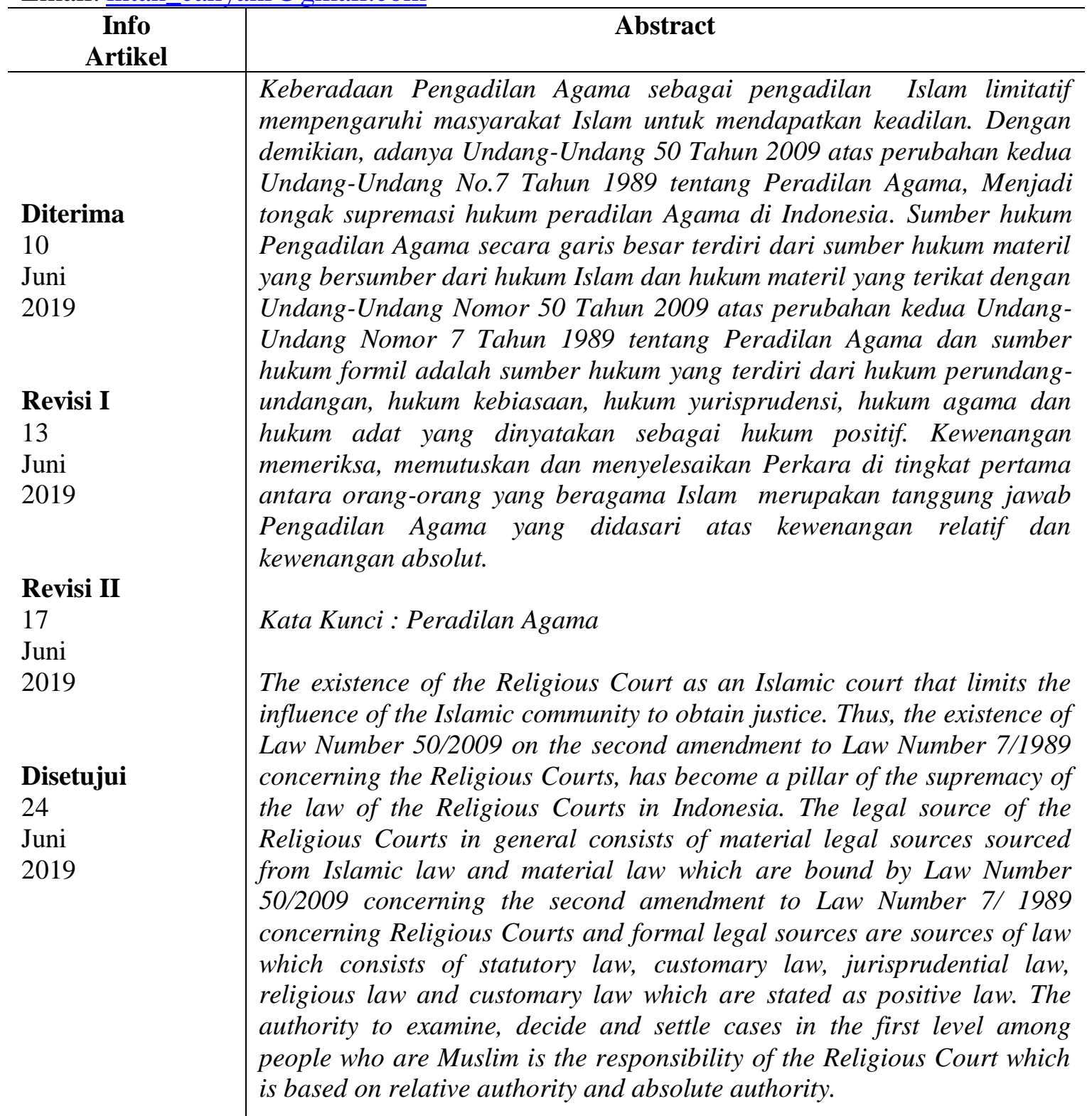

Keywords: Religious Courts 


\section{A. PENDAHULUAN}

Peranan pengadilan tidak dapat disanksikan lagi, sebab dengan Lembaga Pengadilan, segala yang menyangkut hak dan tanggung jawab yang terabaikan dapat diselesaikan, lembaga ini memberikan tempat bahkan membantu kepada mereka yang merasa dirampas hak-haknya dan memaksa kepada pihak-pihak agar bertanggung jawab atas perbuatan yang dilakukan yang merugikan pihak lainnya. Aktivitas Lembaga Pengadilan demikian itu pada dasarnya adalah berupaya menghubungkan rumusanrumusan hukum yang sifatnya masih abstrak, karena dengan melalui bekerjanya Lembaga Pengadilan, hukum itu baru dapat diwujudkan, sebagaimana dikatakan oleh Satjipto Raharjo, bahwa kehadiran lembaga hukum itu merupakan operasionalisasi dari ide rumusan konsep-konsep hukum bersifat abstrak. Melalui lembaga dan bekerjanya lembaga-lembaga itulah, hal-hal yang bersifat abstrak tersebut dapat diwujudkan ke dalam kenyataan. ${ }^{1}$

Penyelesaian perselisihan dan persengketaan yang dilakukan melalui kekuasaan negara dilaksanakan oleh Badan Peradilan, yang memiliki kemampuan untuk bertindak memaksakan keputusannya kepada para pihak dengan menggunakan sistem sanksi tertentu. Pranata peradilan itu amat dibutuhkan oleh masyarakat, apabila cara yang pertama dan cara yang kedua mengalami jalan buntu. Bahkan terhadap tindakan pelanggaran hukum dan kejahatan, peradilan merupakan satu-satunya pranata yang memiliki kemampuan dan wewenang untuk menyelesaikannya. ${ }^{2}$

Lingkungan peradilan yang merupakan kekuasaan kehakiman terbagi menjadi empat, yaitu Peradilan Umum, Peradilan Agama, Peradilan Militer dan Peradilan Tata Usaha Negara. Masing-masing lembaga tersebut memiliki ruang lingkup dan wewenangnya yang diatur dalam perundang-undangan yang keseluruhannya di bawah naungan Mahkamah Agung. Peradilan Agama merupakan peradilan yang memiliki kekhususan dalam cakupan serta wewenangnya. Dimulai dari penyelesaian perkaraperkara tertentu yang kemudian pada golongan rakyat tertentu pula. Hukum Acara Perdata Peradilan Agama adalah hukum yang berfungsi mengatur lalu lintas pemeriksaan perkara di pengadilan dalam lingkungan Peradilan Agama. Dengan menggunakan hukum acara ini para pihak yang bersengketa dapat memulihkan hakhaknya yang telah dirugikan oleh pihak lain melalui pengadilan, tidak main hakim sendiri. Dalam hukum acara perdata diatur hak dan kewajiban yang harus dilakukan oleh masing-masing pihak yang berperkara secara seimbang di depan sidang pengadilan. ${ }^{3}$ Berangkat dari uraian di atas, maka dapat dikemukakan beberapa sub permasalahan yakni bagaimana kedudukan Kekuasaan Kehakiman Peradilan Agama sebagai penegak Hukum Islam, dan bagimana cakupan, wewenang Peradilan Agama serta sumber hukum acara Peradilan Agama?

\footnotetext{
${ }^{1}$ Rusli Muhammad, Potret Lembaga Pengadilan Indonesia (Jakarta: PT Raja Grafindo Persada,2006), h. 4.

${ }^{2}$ Cik Hasan Bisri, Peradilan Agama di Indonesia (Jakarta: PT Raja Grafindo Persada,2003), h.15.

${ }^{3}$ Abdul Halim Talli, Asas-asas Peradilan Dalam Risalah Al-Qada Kritik Terhadap Beberapa Asas Peradilan di Indonesia (Yogyakarta: UII Press Yogyakarta, 2014), h.113-114.
} 


\section{B. METODE PENELITIAN}

Jenis penelitian ini merupakan kepustakaan merupakan pengumpulan data dan informasi yang diperoleh langsung dari berbagai literatur, peraturan perundangundangan, pendapat para ahli hukum, dokumen serta tulisan lain yang terkait materi yang dibahas sebagai penunjang. Data yang diperoleh dianalisis secara kualitatif kemudian disajikan secara deskriptif yaitu menguraikan, menggambarkan, dan menjelaskan sesuai dengan permasalahan yang erat kaitannya dengan penelitian ini.

\section{PEMBAHASAN}

\section{Kedudukan Kekuasaan Kehakiman Peradilan Agama sebagai Penegak Hukum Islam di Indonesia}

Perubahan Undang-Undang Dasar Negara Republik Indonesia tahun 1945 telah membawa perubahan dalam kehidupan ketatanegaraan, khususnya dalam pelaksanaan kekuasaan lembaga peradilan. Perubahan Undang-Undang Dasar Negara Republik Indonesia Tahun 1945, menurut pandangan Satjipto Rahardjo adalah sebuah kenyataan untuk berburu kebenaran walaupun pada masa tertentu harus mengakui kegagalan dan keterbatasannya, sebab kebenaran hasil karya manusia adalah relatif. Berdasarkan perubahan tersebut, di tegaskan bahwa kekuasaan kehakiman dilaksanakan oleh sebuah Mahkamah Agung dan Badan Peradilan yang berada di bawahnya dalam lingkungan Peradilan Umum, lingkungan Peradilan Agama, lingkungan Peradilan Militer, lingkungan Peradilan Tata Usaha Negara, dan oleh sebuah Mahkamah Konstitusi. ${ }^{4}$

Kekuasaan kehakiman menjadi kekuasaan yang fundamental sebagai poros kekuasaan yang mempunyai fungsi menegakkan keadilan tanpa campur kekuasaan lain. Dalam pandangan Bagir Manan menyebutkan beberapa tujuan yang ingin dicapai oleh kekuasaaan kehakiman: 1) sebagai bagian dari sistem pembagian atau pemisahan kekuasaan antara badan-badan penyelengara negara, kekuasaan kehakiman diperlukan untuk menjamin dan melindungi kebebasan individu; 2) kekuasaan kehakiman yang merdeka sangat diperlukan untuk mencegah pemerintahan yang bertindak sewenangwenang dan menindas; 3) kekuasaan kehakiman yang merdeka diperlukan untuk menilai keabsahan suatu peraturan perundang-undangan sehingga sistem hukum dapat dijalankan dan ditegakkan dengan baik. ${ }^{5}$

Independensi Lembaga Peradilan tidak lain adalah kebebasan dan kemandirian Pengadilan dalam menjalankan fungsi dan peranannya. Sedangkan yang dimaksud dengan kebebasan fungsional menurut Oemar Seno Adji bahwa kebebasan fungsional seperti diketahui, mengandung larangan (verbod) menurut hukum tata negara bagi kekuasaan negara lainnya untuk mengadakan intervensi dalam pemeriksaan perkaraperkara oleh hakim, dalam oordeervorming mereka menjatuhkan putusan. Dalam perundang-undangan Indonesia, Lembaga Peradilan mengalami eksistensi pengertian, dengan menyatakan bahwa tidak terbatas pada kebebasan campur tangan dari pihak kekuasaan negara lainnya, melainkan pada kebebasan dari paksaan dan rekomendasi dari pihak ekstra yudisial. ${ }^{6}$ Kemandirian peradilan tidak terlepas dari keberadaan Badan Peradilan di Indonesia. Landasan yuridis mengenai lingkungan peradilan diatur pada

\footnotetext{
${ }^{4}$ Ahmad Mujahidin, Peradilan satu atap di Indonesia (Bandung, PT Refika Aditama, 2007), h.1

${ }^{5}$ Achmad Edi Subiyanto, Mendesain Kewenangan Kekuasaan kehakiman setelah Perubahan UUD 1945, Jurnal Konstitusi, Volume 9, Nomor 4, Desember 2012, h. 665-667.

${ }^{6}$ Ahmad Mujahidin, Peradilan satu atap di Indonesia, h.14 .
} 
Pasal 10 serta pembentukan Pengadilan Khusus dan Mahkamah Syar'iyah diletakkan pada Pasal 15 ayat (1) dan (2) Undang-Undang No. 48 Tentang 2009 yang menyatakan: 1) Pengadilan khusus hanya dapat dibentuk dalam salah satu lingkungan peradilan sebagaimana dimaksud dalan Pasal 10 diatur degan Undang-Undang; 2) Peradilan Syariah Islam di Propinsi Nanggroe Aceh Darussalam merupakan pengadilan khusus dalam lungkungan peradilan agama sepanjang kewenangannya meyangkut kewenangan peradilan agama, dan merupakan peradilan khusus dalam lingkungan peradilan umum, sepanjang kewenangannya menyangkut kewenangan Peradilan Umum. ${ }^{7}$

Kepentingan negara harus terwakili dalam proses-proses penyelenggaraan peradilan, namun kepentingan negara harus mendapat legitimasi dan atau berdasarkan pada hukum, dan sedapat mungkin tidak akan mengorbankan kepentingan rakyat, demikian pula sebaliknya. Oleh karena itu, putusan Lembaga Pengadilan sebagai lembaga integrasi harus memuat dan mewakili ketiga kepentingan itu sehingga semakin memantapkan terwujudnya keadilan yang menjadi tujuan utamanya. ${ }^{8}$ Pelaksanaan sistem peradilan pada hakikatnya sangat berpengaruh pada kepentingan rakyat sebagai pijakan dalam menghadapi persoalan tertentu. Kehadiran asas peradilan yang meneragkan tentang ketidakbolehan menolak perkara dengan dalil hukum tidak ada atau hukum kurang jelas menjadi kekuatan di dalam melindungi kepentingan rakyat pada khususnya. Hal tersebut didasarkan pada Pasal 16 ayat (1) dan (2) Undang-Undang Nomor 48 Tahun 2009 yaitu: 1) Pengadilan tidak boleh menolak untuk memeriksa, mengadili, dan memutus suatu perkara yang diajukan dengan dalil bahwa hukum tidak ada atau kurang jelas, melainkan wajib untuk memeriksa dan mengadili; 2) Ketentuan sebagaimana dimaksud pada ayat (1) tidak menutup usaha penyelesaian perkara perdata secara perdamian. ${ }^{9}$

Peradilan dapat diidentifikasi sebagai bagian dari pranata hukum (legal institusion) untuk memenuhi kebutuhan penegak hukum dan keadilan. Gambaran pertumbuhan dan perkembangan peradilan, dan hukum pada umumnya juga sangat bergantung pada pranata politik yang berbasis pada struktur sosial, pola budaya, dan perkembangan ekonomi. Proses peradilam merupakan sesuatu yang bersifat aktual yang mengacu kepada nilai-nilai yang dianut oleh masyarakat. Peradilan sebagai pranata sosial tidak berdiri dan bekerja secara otonom melainkan berada pada proses pertukaran dengan lingkungannya. ${ }^{10}$ Pentingnya lembaga peradilan sebagai wadah integrasi dari berbagai kepentingan baik kepentingan negara, kepentingan hukum dan kepentingan masyarakat. Lembaga Peradilan menjadi saran integrasi yang harus mampu menyeimbangkan ketiga kepentingan tersebut, tanpa mendominankan atau mengabaikan suatu kepentingan. ${ }^{11}$

\footnotetext{
${ }^{7}$ M. Fauzan, Pokok-pokok Hukum Acara Perdata Peradilan Agama dan Mahkamah Syar'iyah di Indonesia ( Jakarta: Prenada Media Group, 2005), h. 4.

${ }^{8}$ Rusli Muhammad, Potret Lembaga Peradilan Indonesia (Jakarta: PT Rajawali Grafindo Persada, 2006), h. 9.

${ }^{9}$ M. Fauzan, Pokok-pokok Hukum Acara Perdata Peradilan Agama dan Mahkamah Syar'iyah di Indonesia, h. 4.

${ }^{10}$ Cik Hasan Bisri, Peradilan Agama di Indonesia (Jakarta: PT Raja Grafindo Persada 2003), h. 9-10.

${ }^{11}$ Rusli Muhammad, Potret Lembaga Peradilan Indonesia (Jakarta: PT Rajawali Grafindo Persada, 2006), h. 9.
} 
Proses Interaksi dialami oleh masyarakat Islam di Indonesia. Hal itu berlangsung dalam jangka yang panjang, yaitu sejak masyarakat islam menjadi kekuatan politik pada masa kekuasaan Islam hingga sekarang. Salah satu produk interaksi adalah Peradilan Islam di Indonesia, yang secara resmi disebut Peradilan Agama, sebagai salah satu bagian dari peradilan negara. Dengan demikian, maka Peradilan Agama adalah Peradilan Islam di Indonesia. Peradilan agama sebagai perwujudan peradilan Islam di Indonesia dapat dilihat dari beberapa sudut pandang. Secara filosofis peradilan dibentuk dan dikembangkan untuk menegakkan hukum dan keadilan. ${ }^{12}$

Sebenarnya jika ditinjau dari sejarahnya, keberadaan Lembaga Peradilan Agama telah diakui sejak lama. Pemerintah Belanda membentuknya dengan Staatblad (LN) 1882 No. 152 jo Staatblad 1937 untuk Peradilan Agama di Jawa dan Madura, StaatBlad 1937 No. 638 dan 639 di Kalimantan Selatan. Kemudian setelah Indonesia merdeka, pemerintah membentuk Peradilan Agama untuk selain Jawa-Madura dan Kalimantan Selatan dengan peraturan pemerintah Nomor 45 Tahun 1975. Akan tetapi, dalam peraturan-peraturan tersebut tidak diatur tentang hukum acara mengenai tata cara memeriksa, mengadili, dan menyelesaikan perkara. Sehingga para hakim Peradilan Agama mengambil intisari hukum acara yang ada dalam kitab kitab fikih yang dalam penerapannya berbeda antara Pengadilan agama yang satu dengan pengadilan agama yang lain. ${ }^{13}$ Sedangkan produk hukum Undang -Undang Nomor 50 Tahun 2009 atas perubahan kedua Undang- Undang Nomor 7 Tahun 1989 tentang Peradilan Agama, lahir dari konfigurasi politik yang demokratis dan karakter hukum yang responsif. Maka dari segi perspektif materi hukum, politik hukum pemerintah bersifat otonom dan responsif atau populistik, dimana produk hukum ini mencerminkan harapan masyarakat dan rasa keadilan. ${ }^{14}$

Peradilan Agama adalah Peradilan Islam di Indonesia, sebab dari jenis-jenis perkara yang boleh seluruhnya adalah jenis perkara menurut agama Islam. Tegasnya, Pengadilan Agama adalah Peradilan Islam limitatif, yang disesuaikan dengan (dimutatis mutandiskan) dengan keadaan di Indonesia. Di sisi lain, Pengadilan Agama adalah peradilan perdata sedangkan peradilan umum adalah juga peradilan perdata di samping peradilan umum. Jika lihat dari aasas-asas hukum acara, tentulah ada prinsip-prinsip kesamaannya secara umum di samping secara khusus tentu ada pula perbedaan antara Hukum Acara Peradilan Umum dan Hukum Acara Perdata Peradilan Agama. ${ }^{15}$ Dengan kata lain, Peradilan Agama merupakan salah satu pelaksanaan kekuasaan kehakiman yang ikut berfungsi dan berperan menegakkan keadilan, kebenaran, ketertiban, dan kepastian hukum mengenai perkara perdata Islam tertentu. Karenanya, Peradilan Agama ini disebut peradilan khusus.

Secara yuridis Undang-Undang 50 Tahun 2009 tentang Peradilan Agama memberikan landasan Yuridis yang kuat. Dengan penetapan Undang-undang Nomor 50 Tahun 2009 tentang Peradilan Agama tersebut menempatkan Peradilan Agama sama

\footnotetext{
${ }^{12}$ Cik Hasan Bisri, Peradilan Agama di Indonesia, h. 24.

${ }^{13}$ Aris Bintania, Hukum Acara peradilan Agama dalam kerangka Fiqh al-Qadha, (Jakarta, PT Raja Grafindo Persada, 2013), h.2

${ }^{14}$ Abdul halim, Peradilan Agama dalam Politik Hukum Di Indonesia (Jakarta, PT Raja Grafindo Persada, 2002) h. 164

${ }^{15}$ Roihan A. Rasyid, Hukum Acara Peradilan Agama, Edisi Terbaru (Jakarta: PT Grafindo Persada, 2016), h. 6-7
} 
dengan lembaga Peradilan lainya. Tetapi dalam hal kompetensi untuk menyelesaikan perkara tidak sepenuhnya diberikan kewenangan itu, masih ada pilihan hukum bagi pencari keadilan. ${ }^{16}$ Berlakunya Undang-Undang Nomor 50 Tahun 2009 membawa perubahan dasar yang terjadi dalam lingkungan Peradilan Agama, di antaranya; 1) Peradilan Agama telah menjadi peradilan mandiri serta kedudukannya telah sejajar dengan Peradilan Umum, Peradilan Militer,dan Peradilan Tata Usaha Negara. 2) Nama, Susunan dan Wewenang atau kekuasaan serta hukum acara Peradilan Agama telah sama dan seragam diseluruh Indonesia. Terciptanya hukum acara Peradilan agama yang akan memudahkan terwujudnya ketertiban dan kepastian hukum yang berintikan keadilan dalam lingkungan Peradilan Agama. 3) Perlindungan terhadap wanita lebih ditingkatkan salah satunya dengan memberikan hak yang sama kepada istri dalam berproses membela kepentingannya di muka Pengadilan Agama. 4) Dalam penyusunan dan pembinaan hukum nasional 5) Menetapkan upaya pengalihan berbagai asas dan kaidah hukum Islam melalui yurisprudensi. 6) Terlaksananya ketentuan-ketentuan dalam Undang-Undang Pokok Kekuasaan Kehakiman, terutama yang disebut pada Pasal 10 ayat (1) mengenai kedudukan Pengadilan Agama dan Pasal 12 tentang susunan, kekuasaan, dan hukum acaranya.

\section{Sumber Hukum Acara Peradilan Agama}

Menurut Sudikno Mertokusumo bahwa sumber hukum sering digunakan dalam beberapa arti, yaitu: a) sebagai asal hukum atau permulaan hukum misalnya kehendak Tuhan, akal manusia, jiwa bangsa dan sebagainya; b) menunjukkan hukum terdahulu; c) sebagai sumber berlakunya; d) sebagai sumber mengenal hukum misalanya UndangUndang, dokumen dan sebagainya; e) sebagai sumber terjadinya hukum yang menimbulkan hukum. ${ }^{17}$

1) Hukum Materil Peradilan Agama

Menurut Roihan A. Rasyid, Peradilan Agama merupakan peradilan Islam di Indonesia, hal tersebut didasari atas jenis-jenis perkara yang ditangani oleh peradilan agama dan diatur dalam ketentuan agama Islam. Terbentuknya peradilan agama di Indonesia yang bertujuan untuk menegakkan hukum perdata Islam dalam bidang-bidang tertentu seperti perkawinan, kewarisan, hibah, wasiat, wakaf, zakat, infak, sedekah dan ekonomi syari'ah. Semuanya ini sejalan dengan hukum Islam ${ }^{18}$. Sumber hukum materil dari hukum materil Pengadilan Agama adalah bersumber dari hukum Islam. ${ }^{19}$

Hukum Islam merupakan bagian integral ajaran Islam yang tidak dapat dipisahkan dengan kehidupan umat Islam. Menurut Ahmad Azhar Basyir, berdasarkan Falsafah Pancasila dan UUD 1945, legislasi hukum materil Islam merupakan keharusan konstitusional yuridis. Beberapa bagian hukum Islam kemudian benar-benar diangkat dalam peraturan perundang-undangan baik secara tersurat maupun tersirat. Secara hukum materil, lembaga Peradilan Agama dapat menjalankan kewenanganya sebagai peradilan bagi umat Islam di Indonesia untuk memutus perkara tidak lagi secara

\footnotetext{
${ }^{16}$ Supardin, Lembaga Peradilan Agama dan Penyatuan Atap (Makassar, Alauddin University Press, 2012,) h. 77.

${ }^{17}$ Domiri, Analisis tentang Sistem Peradilan Islam di Indonesia, Jurnal Hukum Dan Pembangunan Tahun ke. 47 No. 3Juli -September 2016, h. 334.

${ }^{18}$ Abd. Halim Talli, Peradilan Islam dalam Sistem Peradilan di Indonesia (Cet. I; Makassar: Alauddin University Press, 2011), h. 216.

${ }^{19}$ Domiri, Analisis tentang Sistem Peradilan Islam di Indonesia, h. 334.
} 
langsung menggunakan Al-Quran dan Hadis ataupun sumber-sumber hukum Islam lainnya semisal Ijma, Qiyas, Istihsan, Istihab ataupun kitab-kitab fiqh tertentu yang menjadi standar hukum Islam, ${ }^{20}$ kecuali jika kemudian terjadi pertentangan paham, maka Al-Quran dan standar hukum Islam lainnya dapat dijadikan rujukan secara langsung. Sebagaimana firman Allah dalam QS An-Nisā/4: 59.

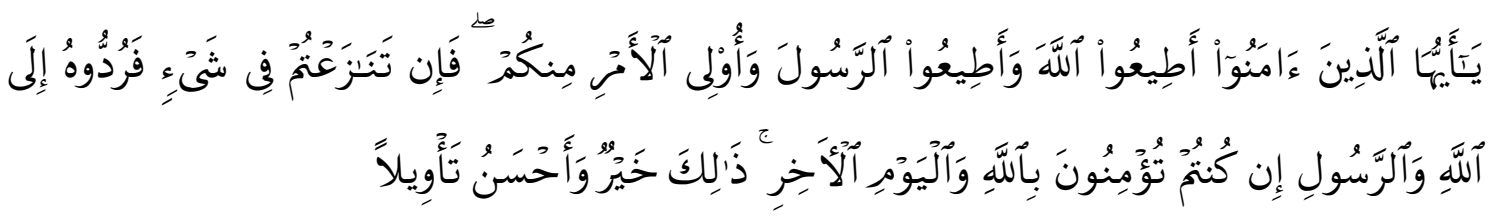

Terjemahnya:

Hai orang-orang yang beriman, taatilah Allah dan taatilah Rasul (Nya), dan ulil amri di antara kamu. kemudian jika kamu berlainan Pendapat tentang sesuatu, Maka kembalikanlah ia kepada Allah (Al Quran) dan Rasul (sunnahnya), jika kamu benar-benar beriman kepada Allah dan hari kemudian. yang demikian itu lebih utama (bagimu) dan lebih baik akibatnya.

Ayat ini menjelaskan tentang perintah untuk mendorong manusia di dalam menciptakan masyarakat adil dan makmur, taat kepada Allah dan Rasul, tunduk kepada ulil amri serta menyelesaikan perselisihan berdasarkan nilai yang diajarkan oleh AlQuran dan Sunnah. Yang demikian itu, nilai-nilai Al-Quran dan Sunnah baik lagi sempurna demi kehidupan dunia maupun akhirat kelak. ${ }^{21}$ Kedudukan Al-Quran sebagai sumber dari segala sumber hukum di dalm tataran hukum Islam dijelaskan pula dalam firman Allah QS Al-Maidah/5:48-49.

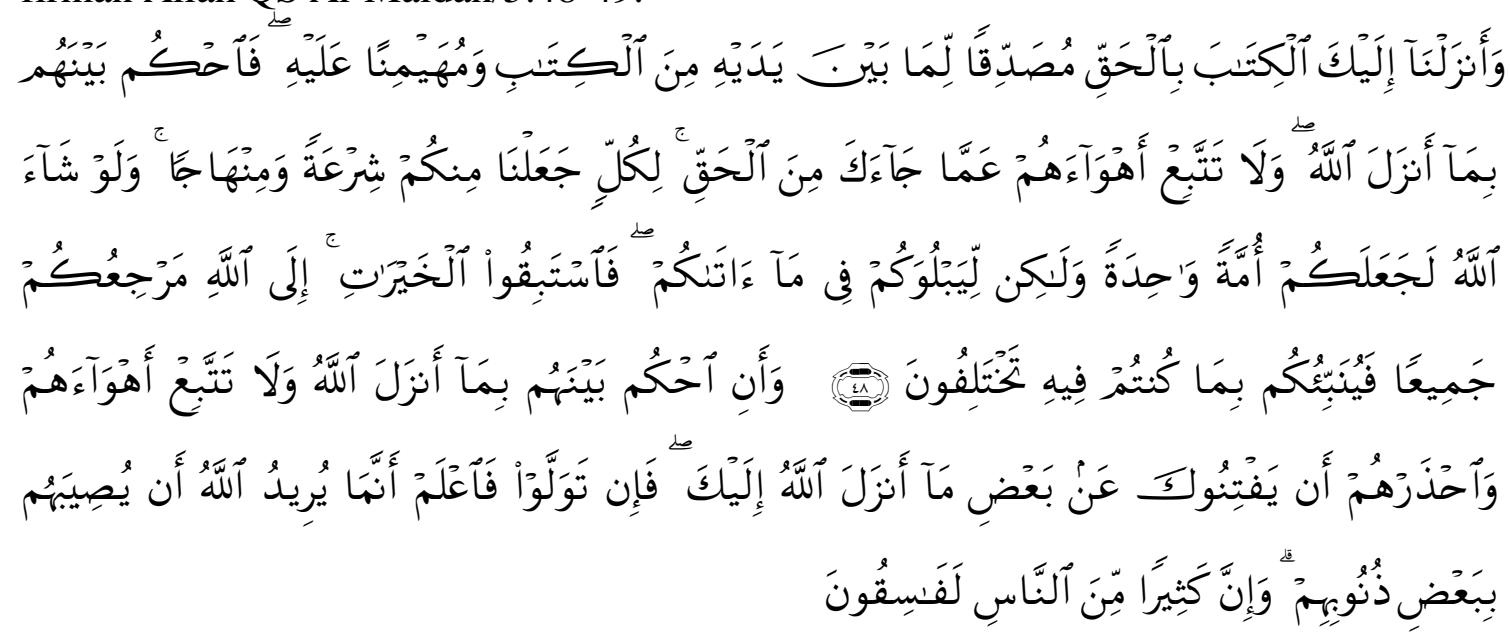

Terjemahnya:

Dan Kami telah turunkan kepadamu Al Quran dengan membawa kebenaran, membenarkan apa yang sebelumnya, Yaitu Kitab-Kitab (yang diturunkan sebelumnya) dan batu ujianterhadap Kitab-Kitab yang lain itu; Maka

${ }^{20}$ Aris Bintania, Hukum Acara Peradilan Agama dalam Kerangka Fiqh al-Qadha, h. 147-148.

${ }^{21}$ M. Quraish Shihab, Tafsir Al-Misbah, Pesan, Kesan, dan Keserasian Al-Quran, Volume 2 (Jakarta: Lentera Hati, 2002), h. 583-584. 
putuskanlah perkara mereka menurut apa yang Allah turunkan dan janganlah kamu mengikuti hawa nafsu mereka dengan meninggalkan kebenaran yang telah datang kepadamu. untuk tiap-tiap umat diantara kamu, Kami berikan aturan dan jalan yang terang. Sekiranya Allah menghendaki, niscaya kamu dijadikan-Nya satu umat (saja), tetapi Allah hendak menguji kamu terhadap pemberian-Nya kepadamu, Maka berlomba-lombalah berbuat kebajikan. hanya kepada Allah-lah kembali kamu semuanya, lalu diberitahukan-Nya kepadamu apa yang telah kamu perselisihkan itu, 49) Dan hendaklah kamu memutuskan perkara di antara mereka menurut apa yang diturunkan Allah, dan janganlah kamu mengikuti hawa nafsu mereka. dan berhati-hatilah kamu terhadap mereka, supaya mereka tidak memalingkan kamu dari sebahagian apa yang telah diturunkan Allah kepadamu. jika mereka berpaling (dari hukum yang telah diturunkan Allah), Maka ketahuilah bahwa Sesungguhnya Allah menghendaki akan menimpakan mushibah kepada mereka disebabkan sebahagian dosa-dosa mereka. dan Sesungguhnya kebanyakan manusia adalah orang-orang yang fasik.

Sejalan dengan itu, Muatan hukum Al-Quran dan Sunnah secara tertulis maupun tersirat telah dimuat di dalam Undang-Undang Nomor 50 Tahun 2009 tentang Perubahan kedua atas Undang-Undang Republik Indonesia Nomor 7 Tahun 1989 tentang Peradilan Agama. Akan tetapi, hukum materilnya masih tetap terikat pada Undang-Undang Nomor 1 Tahun 1974 tentang Perkawinan, Peraturan Pemerintah Nomor 9 Tahun 1975 tentang Peraturan Pelaksanaan Undang-Undang Nomor 1 Tahun 1974 tentang Perkawinan, Peraturan Pemerintah Nomor 28 Tahun 1977 Perwakafan Tanah Milik dan sebagian tercantum dalam Undang-Undang tentang Peradilan Agama, Undang-Undang Nomor 41 Tahun 2004 tentang wakaf, Peraturan Menteri Agama Nomor 1 Tahun 1978 tentang Peraturan Pelaksanaaan PP Nomor 28 Tahun 1977, Peraturan Menteri Agama Nomor 2 Tahun 1987 tentang Wali Hakium, Undang-Undang Nomor 38 tahun 1999 tentang Pengelolaan Zakat, Undang-Undang Nomor 21 Tahun 2008 tentang Perbankan Syari'ah. .

Produk peraturan perundang-undangan yang selanjutnya sebagai representasi hukum Islam adalah Kompilasi Hukum Islam. Kedudukan Kompilasi Hukum Islam merupakan makna kehidupan masyarakat Islam Indonesia yang mengandung norma hukum. Kompilasi Hukum Islam disepakati oleh Alim Ulama Indonesia dan menjadi rangkaian hukum tertulis dan masuk sebagai tata hukum Indonesia di dalam Instrumen Inpres Nomor 1 Tahun 1991. ${ }^{22}$ Secara legitimasi Kompilasi Hukum Islam, Kompilasi Hukum Ekonomi Syariah dan Fatwa Dewan Syariah Majelis Ulama Indonesia digolongankan sebagai hukum materil, ${ }^{23}$ sebagai pedoman untuk menyelesaikan perkara di lingkungan Peradilan Agama. ${ }^{24}$

Legislasi hukum materil Islam dalam tatanan kehidupan bernegara ke dalam berbagai peraturan dan perundang-undangan tersebut, sebagai upaya unifikasi hukum Islam untuk menghindari terjadinya ketidakpastian hukum akibat perbedaan putusan

\footnotetext{
${ }^{22}$ Dadang Hermawan dan Sumardjo, Kompilasi Hukum Islam Sebagai Hukum Materiil Pada Peradilan Agama, Yudisia, Vol. 6, No. 1, Juni 2015, h. 26.

${ }^{23}$ Domiri, Analisis tentang Sistem Peradilan Islam di Indonesia, , h. 335.

${ }^{24}$ A. Basiq Djalil, Peradilan Agama di Indonesia (Jakarta: Pranada Media Group, 2006), h. 158
} 
terhadap perkara antara Pengadilan Agama di berbagai wilayah di Indonesia. ${ }^{25}$ Atas dasar tersebut, kepastian hukum Islam dapat diwujudkan melalui kebenaran. Wujud kebenaran dapat diwujudkan selain berdasarkan alat bukti yang sah dan mencapai batas minimal pembuktian dan kebenaran itu pula harus di yakini oleh hakim sehingga kebenaran itu dianggap bernilai kebenaran hakiki. ${ }^{26}$

2) Hukum Formil Peradilan Agama

Sumber hukum formal di Indonesia terdiri dari hukum perundang-undangan, hukum kebiasaan, hukum yurisprudensi, hukum agama dan hukum adat yang dinyatakan sebagai hukum positif. Keberadaan hukum formil tidak dapat dipungkiri bahwa tujuan utama diajukannya suatu perkara di Pengadilan adalah tegaknya hukum materil. Semua komponen yang terlibat dalam penegakan hukum materil tersebut harus tunduk pada ketentuan hukum acara (formil). ${ }^{27}$ Hukum acara sebetulnya mengabdi kepada hukum material, kedudukan hukum acara pada dasarnya juga mengutamakan kebenaran formal. Namun, tidak berarti hukum acara mengesampingkan kebenaran materil. Dalam hukum acara peradilan Islam atas dasar hadis Rasululah Saw, menerangkan bahwa Allah memerintahkan untuk menyelesaikan perkara menurut zahirnya. Kata zahir bukanlah berarti kebenaran formal menurut istilah Hukum Acara Perdata Umum. Akan tetapi, maksudnya adalah kebenaran hakikat secara formal atau kebenaran materil menurut kemampuan manusia. ${ }^{28}$

Hukum Acara Peradilan Agama khususnya hukum formil menjadi konkret sesuai dengan isi Undang-Undang pada Pasal 54 yang berbunyi Hukum Acara yang berlaku pada Peradilan dalam lingkungan Peradilan Agama adalah Hukum Acara Perdata yang berlaku dalam lingkungan Peradilan Umum, kecuali yang telah diatur dalam Undang-Undang ini”. ${ }^{29}$ Sejak berlakunya Undang-Undang 50 Tahun 2009 atas perubahan kedua Undang-Undang Nomor 7 Tahun 1989 tentang Peradilan Agama menerangkan bahwa hukum acara yang diberlakukan adalah hukum acara perdata yang berlaku pada Peradilan Umum kecuali yang diatur secara khusus dalam Undang-undang lain. Hukum acara yang berlaku di Peradilan Umum adalah HIR dan R.Bg sebagaimana Surat Edaran Mahkamah Agung Republik Indonesia Nomor 19 Tahun1965 dan kemudian dipertegas lagi dengan Surat Edaran Mahkamah Agung Republik Indonesia Nomor 3 Tahun 1965. Pada kesimpulannya hukum acara Peradilan Umum tersebut juga diberlakukan Peradilan Agama sebagaimana diatur dalam Undang-Undang Nomor 1 tahun 1974, Peraturan Pemerintah Nomor 9 Tahun 1975 dan hal-hal lain yang telah diatur dalam Undang-Undang Nomor 7 Tahun 1989 itu sendiri. ${ }^{30}$

Peraturan perundang-undangan tentang hukum acara perdata yang berlaku bagi lingkungan Pengadilan Umum dan Pengadilan Agama, meliputi, Undang-Undang

\footnotetext{
${ }^{25}$ Aris Bintania, Hukum Acara Peradilan Agama dalam Kerangka Fiqh al-Qadha, h. 149.

${ }^{26}$ Abd. Halim Talli, Asas-Asas Peradilan dalam Risalah Al-Qada terhadap Beberapa Asas Peradilan di Indonesia, h.131.

${ }^{27}$ Abd. Halim Talli, Asas-Asas Peradilan dalam Risalah Al-Qada terhadap Beberapa Asas Peradilan di Indonesia, h. 114.

${ }^{28}$ Roihan A. Rasyid, Hukum Acara Peradilan Agama, h. 9-10.

${ }^{29}$ Roihan A. Rasyid, Hukum Acara Peradilan Agama, h.20.

${ }^{30}$ Abdul Manan, Etika Hakim dalam Penyelenggaraan Peradilan (Jakarta: Kencana, 2010), h.
} 181. 
Nomor 48 Tahun 2009 tentang Ketentuan-Ketentuan Pokok Kekuasaan Kehakiman dan Undang-Undang Nomor 3 Tahun 2009 tentang Mahkamah Agung.

Ada tiga peraturan yang dikeluarkan setelah berlakunya Undang-Undang 50 tahun 2009 atas perubahan kedua Undang-Undang Nomor 7 Tahun 1989 tentang Peradilan Agama: ${ }^{31}$

1. Surat Edaran Mahkamah Agung Nomor 2 Tahun 1990 tentang Petunjuk Pelaksanaan Undang-Undang Nomor 7 Tahun 1989 tetang Peradilan Agama.

2. Instruksi Presiden Nomor 1 Tahun 1991 tentang Penyebarluasan Kompilasi Hukum Islam.

Undang-Undang yang mengatur tentang Peradilan Agama telah mengalami amandemen sebanyak dua kali. Amandemen pertama Undang-undang Peradilan Agama adalah lahirnya Undang-Undang Nomor 3 Tahun 2006 tentang perubahan atas UndangUndang Nomor 7 Tahun 1989 tentang Peradilan Agama. Perubahan pertama terjadi pada era reformasi, pada perubahan tersebut belum secara menyeluruh mengatur penyatuan atap Lembaga Peradilan Agama pada Mahkamah Agung. ${ }^{32}$ Dan tahun 2009 Undang-Undang Peradilan Agama kembali diamandemenkan melalui Undang-Undang Nomor 50 Tahun 2009 sebagai amandemen kedua dari Undang-Undang Nomor 7 Tahun 1987.

\section{Kewenangan Peradilan Agama}

Susunan pengadilan terdiri dari pimpinan, hakim anggota, panitera, sekertaris dan juru sita. Pengadilan bertugas memeriksa, memutuskan dan menyelesaikan perkara baik perkara perdata maupun perkara pidana di tingkat pertama. ${ }^{33}$ Tindakan pengadilan Agama di dalam melaksanakan tugas disebut Peradilan Agama. Peradilan Agama merupakan salah satu diantara tiga peradilan khusus di Indonesia. Dikatakan peradilan khusus dikarenakan Peradilan Agama mengadili perkara-perkara tertentu atau mengenai golongan rakyat tertentu. ${ }^{34}$ Kekhususan tersebut terlihat dalam tugas pokok Pengadilan Agama untuk memeriksa, mengadili, dan memutuskan perkara yang menjadi kewenagannya. ${ }^{35}$ Kewenangan atau kompetensi sering disebut dengan kekuasaan. Menurut Barda Nawawi Arif, kekuasaan Lembaga Peradilan dilatarbelakangi sebagai bentuk kekuasaan negara di dalam menegakkan hukum dan keadilan demi terselenggaranya negara hukum Republik Indonesia. Hakekat kekuasaan menurut Karl Olivecrone mengatakan kekuasaan sebagai kekuatan yang terorganisasi. Sejalan dengan itu, kekuasaan menjadi kemampuan umum di dalam menjamin pelaksanaan pelaksanaan kewajiban yang mengikat unit organisasi dalam suatu sistem. ${ }^{36}$

Peradilan Agama menetapkan dan menegakkan hukum dan keadilan berdasarkan Pancasila dan Undang-Undang Dasar Negara Republik Indonesia 1945 sesuai Pasal 2 ayat (2) Undang-Undang RI Nomor 48 Tahun 2009. Hal tersebut ditegasakan pula dalam konsideran huruf a Undang-Undang Nomor 48 Tahun 2009 menyatakan

\footnotetext{
${ }^{31}$ Supardin, Lembaga Peradilan Agama dan Penyataan Atap, h. 78.

${ }^{32}$ Supardin, Lembaga Peradilan Agama dan Penyatuan Atap, h. 89-90.

${ }^{33}$ Abdulkadir Muhammad. Hukum Acara Perdata Indonesia (Bandung: PT Citra Aditya Bakri, 2012), h . 24.

${ }^{34}$ Roihan A. Rasyid, Hukum Acara Peradilan Agama, h. 5-6.

${ }^{35}$ Undang-Undang Nomor 50 Tahun 2009 tentang Peradilan Agama.

${ }^{36}$ Ibnu Subarkah, Dilematika Kekuasaan Lembaga Peradilan Dan Keadilan Dalam Frame Desentralisasi Pemerintahan (Suatu Common Sense), Jurnal Konstitusi,Vol. IV, No.1, Juni 2011, h. 144.
} 
Andi Intan Cahyani

kekuasaan kehakiman menurut Undang-Undang Dasar Negara RI Tahun 1945 merupakan kekuasaan kehakiman yang merdeka yang dilakukan oleh sebuah Mahkamah Agung dan Badan Peradilan utamanya Peradilan Agama untuk menyelenggarakan peradilan guna menegakkan hukum dan keadilan. ${ }^{37}$

Kewenangan peradilan dalam kaitannya dengan Hukum Acara Perdata, biasanya menyangkut dua hal, yaitu kewenagan relatif dan absolut. Sebagai peradilan khusus Pengadilan Agama memiliki kewenagan relatif yang diartikan sebagai kekuasaan pengadilan yang satu jenis dan satu tingkatan, dalam perbedaannya dengan kekuasaan pengadilan yang sama jenis dan sama tingkatan lainnya, ${ }^{38}$ misalnya antara Pengadilan Agama Gowa dengan Pengadilan Agama Takalar yang sama sebagai lingkungan Pengadilan Agama dan satu tingkatan pada tingkat pertama. Dengan demikian, kewenangan relatif memiliki urgensitas yang sehubungan dengan Pengadilan Agama mana orang akan mengajukan perkara dan hak eksepsinya. Jadi, masing-masing Pengadilan Agama mempunyai wilayah hukum ( yurisdiksi relatif) tertentu meliputi satu kotamadya atau satu kabupaten. Pada Pasal 4 ayat 1 Undang- Undang Nomor 50 Tahun 2009 bahwa " Pengadilan Agama berkedudukan di kota madya atau ibu kota kabupaten dan daerah hukumnya meliputi kota madya atau kabupaten". ${ }^{39}$ Pada dasarnya tempat kedudukan Pengadilan Agama ada di kota madya ata ibu kota kabupaten yang daerah hukumnya meliputi wilayah kota madya atau kabupaten, tertapi tidak menutup kemungkinan adanya suatu pengecualian.

Kewenagan absolut merupakan kewenangan pengadilan yang berhubungan dengan jenis perkara atau jenis pengadilan atau tingkat pengadilan dalam perbedaanya adalah jenis perkara atau jenis pengadilan atau tingkatan pengadilan lainnya. Kekuasaan absolut Pengadilan Agama diharuskan untuk meneliti perkara yang diajukan kepadanya apakah termasuk kekuasaan absolut pengadilan atau bukan. Jika jelas bukan termasuk kekuasaan absolut, Pengadilan Agama dilarang menerima apalagi memeriksa perkara tersebut. Rumusan kewenagan Pengadilan Agama terdapat dalam Pasal 49 Undang-Undang Nomor 50 Tahun 2009 tentang Pengadilan Agama.

Kewenangan Pengadilan Agama mengalami perubahan pasca adanya UndangUndang Republik Indonesia Nomor 3 Tahun 2006 tentang perubahan atas UndangUndang Nomor 7 Tahun 1987 tentang Pengadilan Agama. Pengadilan Agama semulanya bertugas dan berwenang memeriksa, memutuskan dan menyelesaikan perkara di tingkat pertama di bidang perkawinan, kewarisan, wasiat, dan hibah, serta wakaf dan sedekah sesuai dengan Undang-Undang Nomor 7 Tahun 1987. Akan tetapi, pada Undang-Undang Nomor 3 Tahun 2006 tentang Pengadilan Agama, kewenangan Pengadilan Agama mengalami penambahan pada perkara yang menyangkut infaq, zakat serta ekonomi syariah. Sejauh ini, kewenangan absolut Pengadilan Agama masih bertugas pada 9 bidang saja sesuai Pasal 49 Undang-Undang Nomor 3 Tahun 2006. Meskipun Undang-Undang Pengadilan Agama kembali diubah atas Undang-Undang Nomor 50 Tahun 2009.

Menurut Yahya Harahap, mengenai ketentuan Pasal 2 dan Pasal 49 UndangUndang Republik Indonesia Nomor 3 Tahun 2006 Jo. Undang-Undang Republik Indonesia Nomor 50 Tahun 2009 menegaskan bahwa: a) para pihak yang bersengketa

\footnotetext{
${ }^{37}$ Abd Halim Talli, Asas-Asas Peradilan dalam Risalah Al-Qada, 117-118.

${ }^{38}$ Roihan A. Rasyid, Hukum Acara Peradilan Agama, h. 25.

${ }^{39}$ Undang-Undang Nomor 50 Tahun 2009 tentang Peradilan Agama.
} 
adalam pemeluk agama Islam; 2) Perkara perdata yang disengketakan terbatas mengenai perkara bidang perkawinan, waris, wasiat, hibah, wakaf, zakat, infaq, shadaqah dan ekonomi syariah; c) hubungan hukum yang melandasi keperdataan tersebut berdasarkan hukum Islam. Dengan demikian, asas personalitas keislaman di dalam kewenangan absolut meliputi dua hal, yaitu: 1) kedua belah pihak, atau para pihak harus sama-sama beragama Islam, dan 2) hubungan hukum yang mengikat pada perkara berdasarkan hukum Islam. Karenanya Peradilan Agama memutuskan dan menyelesaikan perkara berdasarkan hukum Islam. ${ }^{40}$ Peradilan Agama sebagai penegak hukum di Indonesia melindungi pihak yang membutuhkan keadilan menjadikan masyarakat khususnya umat Islam untuk mendapatkan keadilan dan melingdungi kepentingannya.

\section{PENTUTUP}

\section{Kesimpulan}

1. Kekuasan kehakiman dilaksanakan oleh Mahkamah Agung dana Badan Peradilan dibawahnya seperti lingkungan Peradilan Umum, lingkungan Peradilan Agama, lingkungan Peradilan Militer, lingkungan Peradilan Tata Usaha Negara.

2. Sumber hukum Pengadilan Agama secara garis besar terdiri dari sumber hukum materil yang bersumber dari hukum Islam dan hukum materil yang terikat dengan Undang-Undang Nomor 50 Tahun 2009 atas perubahan kedua UndangUndang Nomor 7 Tahun 1989 tentang Peradilan Agama dan sumber hukum formil adalah sumber hukum yang terdiri dari hukum perundang-undangan, hukum kebiasaan, hukum yurisprudensi, hukum agama dan hukum adat yang dinyatakan sebagai hukum positif.

3. Pengadilan Agama bertugas dan berwenang memeriksa, memutus, dan menyelesaikan perkara-perkara di tingkat pertama antara orang-orang yang beragama Islam. Kewenangan Pengadilan Agama menyangkut dua hal baik kewenangan relatif maupun kewenangan absolut. Kewenangan relatif Pengadilan Agama diartikan sebagai kekuasan pengadilan khususnya yuridiksi atau wilayah hukum pengajuan perkara dan hak eksepsi. Berbeda halnya dengan kewenangan absolut sebagai kewenagan pengadilan yang berhubungan dengan jenis perkara yang ditangani dalam lembaga pengadilan utamanya Pengadilan Agama yang meliputi, perkawinan, kewarisan, wasiat, hibah, wakaf, sedekah infaq, zakat serta ekonomi syariah.

\section{Saran}

Dengan adanya tulisan mengenai Peradilan Agama ini dimungkinkan lebih mengetahui kedudukan kekuasaan kehakiman Pengadilan Agama sebagai penegak Hukum Islam serta termasuk kewenangan dan sumber hukumnya. Kemudian dari hasil beberapa amandemen setelahnya dapat memperluas lagi jangkauan ilmu tentang Peradilan Agama sendiri sekaligus Hukum Acara Peradilan Agama.

${ }^{40}$ Abd Halim Talli, Asas-Asas Peradilan dalam Risalah Al-Qada terhadap Beberapa Asas Peradilan di Indonesia, h. 117. 


\section{DAFTAR PUSTAKA}

Muhammad, Rusli. Potret Lembaga Pengadilan Indonesia. Jakarta: PT Raja Grafindo Persada, 2006.

Bisri, Cik Hasan. Peradilan Agama di Indonesia. Jakarta: PT Raja Grafindo Persada, 2003.

Talli, Abdul Halim. Asas-asas Peradilan Dalam Risalah Al-Qada Kritik Terhadap Beberapa Asas Peradilan di Indonesia. Yogyakarta: UII Press Yogyakarta, 2014.

Mujahidin, Ahmad. Peradilan satu atap di Indonesia. Bandung, PT Refika Aditama, 2007.

Subiyanto, Achmad Edi. Mendesain Kewenangan kekuasaan kehakiman setelah Perubahan UUD 1945, Jurnal Konstitusi, Volume 9, Nomor 4, Desember 2012.

M. Fauzan. Pokok-pokok Hukum Acara Perdata Peradilan Agama dan Mahkamah Syar'iyah di Indonesia. Jakarta: Prenada Media Group, 2005.

Muhammad, Rusli. Potret Lembaga Peradilan Indonesia. Jakarta: PT Rajawali Grafindo Persada, 2006.

Bisri, Cik Hasan. Peradilan Agama di Indonesia. Jakarta: PT Raja Grafindo Persada 2003.

Muhammad, Rusli. Potret Lembaga Peradilan Indonesia. Jakarta: PT Rajawali Grafindo Persada, 2006.

Bintania, Aris. Hukum Acara peradilan Agama dalam kerangka Fiqh al-Qadha. Jakarta, PT Raja Grafindo Persada, 2013.

Halim, Abdul. Peradilan Agama dalam Politik Hukum Di Indonesia. Jakarta, PT Raja Grafindo Persada, 2002.

Rasyid, Roihan A. Hukum Acara Peradilan Agama, Edisi Terbaru. Jakarta: PT Grafindo Persada, 2016.

Supardin. Lembaga Peradilan Agama dan Penyatuan Atap. Makassar, Alauddin University Press, 2012.

Domiri. Analisis tentang Sistem Peradilan Islam di Indonesia, Jurnal Hukum Dan Pembangunan Tahun ke. 47 No. 3Juli -September 2016.

Talli, Abd. Halim. Peradilan Islam dalam Sistem Peradilan di Indonesia (Cet. I; Makassar: Alauddin University Press, 2011.

Shihab, M. Quraish. Tafsir Al-Misbah, Pesan, Kesan, dan Keserasian Al-Quran, Volume 2, Jakarta: Lentera Hati, 2002.

Dadang Hermawan dan Sumardjo, Kompilasi Hukum Islam Sebagai Hukum Materiil 
Peadilan Agama sebagai Penegak Hukum Islam di Indonesia

Andi Intan Cahyani

Pada Peradilan Agama, Yudisia, Vol. 6, No. 1, Juni 2015.

Djalil, A. Basiq. Peradilan Agama di Indonesia. Jakarta: Pranada Media Group, 2006.

Manan, Abdul. Etika Hakim dalam Penyelenggaraan Peradilan. Jakarta: Kencana, 2010.

Muhammad. Abdulkadir. Hukum Acara Perdata Indonesia. Bandung: PT Citra Aditya Bakri, 2012.

Ibnu Subarkah, Dilematika Kekuasaan Lembaga Peradilan Dan Keadilan Dalam Frame Desentralisasi Pemerintahan (Suatu Common Sense), Jurnal Konstitusi,Vol. IV, No.1, Juni 2011. 